\title{
Effectiveness of Rapid Transition to Online Teaching during COVID 19: An Online Cross-Sectional Survey of Students' and Teachers' Perceptions in a West Indian Dental School
}

\author{
Reisha Rafeek ${ }^{*}$, Bidyadhar Sa ${ }^{2}$, Patrick Harnarayan ${ }^{3}$, Niall Farnon ${ }^{3}$, Shala Singh ${ }^{3}$, \\ Stanley Giddings ${ }^{3}$, Sandra D. Reid ${ }^{3}$
}

${ }^{1}$ School of Dentistry, Faculty of Medical Sciences, The University of the West Indies, St. Augustine Campus, Trinidad \& Tobago ${ }^{2}$ Centre for Medical Sciences Education, Faculty of Medical Sciences, The University of the West Indies, St. Augustine Campus, Trinidad \& Tobago

${ }^{3}$ School of Medicine, Faculty of Medical Sciences, The University of the West Indies, St. Augustine Campus, Trinidad \& Tobago Email: ^reisha.rafeek@sta.uwi.edu

How to cite this paper: Rafeek, R., Sa, B., Harnarayan, P., Farnon, N., Singh, S., Giddings, S., \& Reid, S. D. (2021). Effectiveness of Rapid Transition to Online Teaching during COVID 19: An Online Cross-Sectional Survey of Students' and Teachers' Perceptions in a West Indian Dental School. Creative Education, 12, 1222-1234.

https://doi.org/10.4236/ce.2021.126092

Received: April 21, 2021

Accepted: June 7, 2021

Published: June 10, 2021

Copyright $\odot 2021$ by author(s) and Scientific Research Publishing Inc. This work is licensed under the Creative Commons Attribution International License (CC BY 4.0).

http://creativecommons.org/licenses/by/4.0/

\section{(c) (i) Open Access}

\begin{abstract}
Objectives: The sudden advent of the COVID pandemic resulted in limited face to face interactions and the dental school in the University of the West Indies was challenged to complete the final year with a rapid transition to online teaching. This study examined students' and teachers' perceptions of the effectiveness of emergency remote online teaching and challenges experienced. Materials and Methods: Two independent online cross-sectional surveys were administered on the perception of the online learning environment and challenges experienced and effectiveness of strategies used. Overall thirty three dental students and eleven clinical academic teachers participated. Statistical analysis: Reliability of the questionnaire was determined. Chi-squared $\left(\chi^{2}\right)$ tests were applied for determining the perceptions of students and teachers towards online teaching. Frequencies and percentages were also computed. Results: The majority of students $(60.6 \%-69.7 \%)$ perceived that online teaching strategies enhanced their clinical reasoning and critical thinking skills in clinical practice and found it easy to adapt. However, the majority (87.9\%) perceived it to be somewhat or not effective at all in acquiring clinical skills. The main challenge experienced was connectivity to the internet $(87.9 \%)$. The majority of teachers $(72.7 \%-92.9 \%)$ perceived that they effectively communicated with the students and engaged students in clinical reasoning and critical thinking, but 50\% did not think they prepared
\end{abstract}


students to practice clinical skill. Conclusions: Students' perceptions are similar to teachers' perceptions in that both are positive to the online teaching strategies but both groups reflected concerns over the acquisition of clinical skills.

\section{Keywords}

COVID-19 Pandemic, Dental Students, Perceptions, Online Teaching, Rapid Transition

\section{Introduction}

The epidemic of coronavirus disease 2019 (COVID-19) was reported in Wuhan, China December 2019 (Phelan et al., 2020) and in January, 2020 the Chinese Centre for Disease Control announced a novel coronavirus (SARS-COVID-2) as the causative pathogen for COVID-19 (Li et al., 2020). The disease was declared a global pandemic on March 11th, 2020 by the World Health Organization (WHO) (WHO, 2019) and Trinidad \& Tobago, a twin-island state in the Caribbean, was no exception. On March $12^{\text {th }}$, the first COVID-19 case was diagnosed and on March $15^{\text {th }}$, the government of Trinidad \& Tobago mandated the closure of schools which included Universities and the School of Dentistry, The University of the West Indies (UWI). This had an immediate impact on teaching and the delivery of the dental curriculum.

In the US, the Occupational Safety and Health administration classified dentists in the very high-risk category because of the potential for exposure to coronavirus through aerosol-generating procedures (AGPs) (US Department of Labor, 2020) and the Centre for Disease Control (CDC) issued guidance for Dental Settings (CDC, 2019) which the local Dental Council of Trinidad \& Tobago (DCTT) used to issue best practice guidelines for dentistry in the country. With the sudden advent of the COVID pandemic and the need to limit face to face interactions and remove students from the clinical environment, the School of Dentistry, UWI was challenged to complete the final year teaching with rapid implementation of online lectures and clinical skills training via case-based learning and clinical videos. The biggest challenge has been to postpone direct patient care (Iyer et al., 2020).

A survey of the 67 dental schools in the USA showed that most dental schools have suspended clinical care except for dental emergencies that are seen by faculty or residents (Iyer et al., 2020). Worldwide, one of the earliest reports to emerge on the impact of COVID-19 on dentistry was from China (Meng et al., 2020) which discussed the emerging and future challenges faced at The School and Hospital of Stomatology, Wuhan University. Dental students were not required to return to classes and were learning online. In the dental school setting, dental education in this COVID-19 pandemic must be carefully considered 
(Peng et al., 2020). A survey of 69 of the 153 European dental schools also reported having very limited clinics providing only emergency dental treatment or urgent non-delayable treatment provided by senior staff or postgraduates. Non-clinical teaching was moved to online mode (Quinn et al., 2020). Brazilian and Australian experiences have also been reported. Brazil has over 500 dental schools and the second-highest infection rate after the USA at the time of writing. Face to face classes were suspended as well as clinics and online teaching was implemented (Peres et al., 2020). In contrast, Australia has only 12 dental schools, low infection rates and all clinical and preclinical activities were suspended from mid-March and moved to online activities utilizing platforms such as Microsoft Teams and Backboard Collaborate ULTRA (Peres et al., 2020).

The UWI School of Dentistry which started in 1989 is the only one in Trinidad (Rafeek et al., 2004) and is only one of two dental schools in the English-speaking Caribbean. There was a rapid implementation of online teaching strategies to assist faculty via a series of workshops put on by the Centre for Excellence in Teaching and Learning (CETL) at the UWI from March 2020 through April. There was a steep learning curve for faculty to come on board from mostly face to face teaching, with didactic, preclinical laboratory classes and clinics to shifted to online teaching using the UWI's online platform called myeLearning, a moodle-based platform, utilizing Blackboard Collaborate. Zoom and Schoology online platforms were also used as adjuncts. All didactic teaching moved to emergency remote online teaching and clinical teaching as well via case-based learning including the use of videos. Assessments were also conducted online in the form of written reports and computer-based examinations. This pandemic has brought challenges worldwide to universities and specifically whether the faculty can deal with the existing technology and if they had enough infrastructure or resources to facilitate online teaching from home immediately as computers and IT equipment at home may be in heavy demand by other members of the family at home working or studying (Sahu, 2020).

This study will examine student and teacher perceptions of the effectiveness of emergency remote online teaching at the School of Dentistry, Faculty of Medical Sciences at the St. Augustine campus of the University of the West Indies.

\section{Materials and Methods}

\subsection{Research Design}

To realize the study aims, an online cross-sectional survey approach was adopted and the participants were asked to complete an online questionnaire created using Google Forms.

\subsection{Participants}

All students and teachers who participated in online clinical skills teaching for final year Doctor of Dental Surgery (DDS) students in the UWI from March June 2020 formed the part of the study population recruited through conveni- 
ence sampling technique.

\subsection{Study Instrument}

Two data collection instruments, one for measuring students perception of online teaching during COVID 19 and other for teachers, were designed based on literature and practical issues experienced because of the sudden transition to online teaching during COVID 19 pandemic. The content validity of the questionnaires was ensured by SR and RR (clinical teachers with rich experience) and BS (a medical education expert). The first part of the questionnaire collected data on demographic details of respondents, teaching strategies used during emergency remote teaching for both students and teachers.

The student perception of the recently completed online teaching was evaluated under the domains such as Online Learning Environment and Challenges experienced using 4 point Likert scales as follows: attributes from strongly disagree (score of 1 ) to strongly agree (score of 4 ). Further, the effectiveness of online teaching strategies in term of remembering understanding, acquiring, supplementing, self-study of clinical skills and preparing for OSCE/clinical clerkship examinations was assessed on a 4-point scale: Not Effective at all (Score of 0) Somewhat Effective (Score of 1), Effective (Score of 2) to Very Effective (Score of 3).

The teacher perception of completed online teaching was evaluated under the domains such as Online Learning Environment and Technical Support experienced using 4 point Likert scales as follows: attributes from strongly disagree (score of 1 ) to strongly agree (score of 4 ).

\subsection{Statistical Analysis}

The data were entered into the Statistical Package for the Social Sciences (SPSS) version 24.0 (IBM Corporation, Armonk, NY, USA). Mean and standard deviation (SD) were calculated for the data on the age of students and teachers and year of experience on online teaching for teachers. Cronbach's Alpha was calculated to establish the reliability of the instruments used. Specifically, percentages, median, interquartile range, and chi-square test of goodness of fit were used to determine if the distribution of frequencies of responses in each item were sufficiently different to reject the null hypothesis that the distribution was due to chance. The critical value used to reject the null hypothesis was $p \leq .05$ and $p \leq .01$. Further Inter Quartile Range (IQR) was also computed to find out how middle values are spread out. The information collected from open-ended questions were collated and presented thematically. It is to be noted that the 4-point teacher perception scale is was reduced to two-point Strongly Agree - Agree (\%) and Strongly Disagree Disagree (\%) because $100.0 \%$ cells have expected frequencies of less than 5 .

\subsection{Ethical Approval}

Ethical approval was obtained from the Institutional Review Board, The University of the West Indies, Faculty of Medical Sciences, St Augustine Campus, Trinidad (CREC-SA.0434/07/2020). 


\section{Results}

\subsection{Students}

A total of 33 dental students in final year participated in the study which is a response rate of $94.3 \%$. Among these participants 31 (93.9\%) were female and 2 $(6.1 \%)$ were male. The ages ranged from 23 - 35 years old with a mean age of $25.45 \pm 3.23$. The Cronbach's alpha of the students' questionnaire was found to be .838 which is a very good level of reliability. The online teaching strategies experienced by the students are shown in Table 1 . The vast majority of strategies used were discussion of clinical cases and the use of Powerpoint presentation, followed by online simulations and clinical videos recorded by others. All $\chi^{2}$ values in Table 1 were found to be statistically significant except Online simulations by others $(p<.01)$.

\subsection{Student Perception of the Effectiveness of Online Teaching Strategies}

Table 2 reveals that a majority of students $(87.7 \%-63.6 \%$, with Median $=3$, IQR $=1$ or 0 ) perceived that lecturers created a stimulating online environment, were skillful at online delivery, communicated effectively during online delivery, helpful in giving formative feedback and more so students were feeling connected with them. The majority of students $(84.9 \%-94 \%$, with Median $=3$, IQR $=1$ ) were also of the view that online teaching strategies have enhanced their clinical reasoning skills and prepared them for critical thinking in clinical practice. Nearly two-third students $(63.6 \%$, with Median $=3, \mathrm{IQR}=1)$ were happy to recommend continued use of online strategies in the teaching of clinical skills. In terms of the challenges the students experienced, the vast majority $(87.9 \%$, with Median $=3, \mathrm{IQR}=1$ ) had problems with connectivity or internet and while a little less than half $(48.5 \%$, with Median $=3, \mathrm{IQR}=1)$ had experienced some sort of distraction during remote teaching. All $\chi^{2}$ values in Table 2 were found to be statistically significant $(P<.01)$.

\subsection{Student Perception of the Effectiveness of Online Teaching Strategies for Clinical Skills}

Table 3 shows, when questioned specifically about the use of online strategies in remembering, understanding and supplementing clinical skills with about two-thirds $(66.7 \%-69.7 \%$, with Median $=1$, IQR $=1)$ perceived it to be only somewhat effective or not effective at all. The majority $(87.9 \%$, with Median $=0$, IQR $=1$ ) perceived it to be somewhat or not effective at all in acquiring clinical skills. In terms of the online strategies preparing them for their final clinical clerkship examination over three-quarters perceived it to be only somewhat effective $(42.4 \%)$ or not effective at all $(33.3 \%$, with Median $=1$, IQR $=2)$. All $\chi^{2}$ values were found to be statistically significant (either $P<.01$ or $P<.05$ ) as indicated in Table 3 except for student perception of the effectiveness of online teaching in preparing for OSCE/Clinical clerkship examinations. 
Table 1. Teaching strategies.

\begin{tabular}{llllll}
\hline $\begin{array}{l}\text { What online teaching strategies did you experience } \\
\text { during the period of emergency remote teaching? }\end{array}$ & No $(\%)$ & Yes $(\%)$ & Total & Chi-Squared $\left(\chi^{2}\right)$ & $P$-value \\
\hline Clinical videos (recorded at the UWI) & $30(90.9)$ & $3(9.1)$ & 33 & $22.091^{*}$ & .000 \\
Clinical videos (recorded by others e.g. YouTube videos) & $23(71.9)$ & $9(28.1)$ & 32 & $6.125^{*}$ & .013 \\
Online simulations & $18(56.3)$ & $14(43.7)$ & 32 & .500 & .480 \\
PowerPoint presentation & $1(3.0)$ & $32(97.0)$ & 33 & $29.121^{*}$ \\
Demonstration of skills by lecturer & $24(72.7)$ & $9(27.3)$ & 33 & $6.818^{*}$ & .000 \\
Virtual ward rounds/clinic visits & $32(97.0)$ & $1(3.0)$ & 33 & $29.121^{*}$ \\
Discussion of clinical cases & $0(0)$ & $33(100)$ & 33 & $\begin{array}{l}\text { This variable is constant. } \\
\chi^{2} \text { cannot be performed. }\end{array}$ \\
\hline
\end{tabular}

Table 2. Student perception of the effectiveness of online teaching strategies.

\begin{tabular}{|c|c|c|c|c|c|c|c|c|}
\hline Item & $\begin{array}{l}\text { Strongly } \\
\text { Agree (\%) }\end{array}$ & $\begin{array}{l}\text { Agree } \\
(\%)\end{array}$ & $\begin{array}{l}\text { Disagree } \\
(\%)\end{array}$ & $\begin{array}{l}\text { Strongly } \\
\text { Disagree (\%) }\end{array}$ & Total & $\begin{array}{l}\text { Chi-Squared } \\
\left(\chi^{2}\right)\end{array}$ & $P$-value & $\begin{array}{l}\text { Median } \\
\text { (IQR) }\end{array}$ \\
\hline \multicolumn{9}{|l|}{ Online Learning Environment } \\
\hline $\begin{array}{l}\text { The lecturer created an enthusiastic/stimulating learning } \\
\text { environment }\end{array}$ & NR & $21(63.6)$ & $11(33.3)$ & $1(3.0)$ & 33 & $18.182^{*}$ & .000 & $3(1)$ \\
\hline I felt my lecture was skilled at online teaching & $1(3.0)$ & $24(72.7)$ & $6(18.2)$ & $2(6.1)$ & 33 & $41.788^{*}$ & .000 & $3(1)$ \\
\hline $\begin{array}{l}\text { Lecturers were effective in communicating during online } \\
\text { delivery }\end{array}$ & $3(9.1)$ & $26(78.8)$ & $4(12.1)$ & NR & 33 & $30.727^{*}$ & .000 & $3(0)$ \\
\hline Lecturers were helpful in giving formative feedback & $3(9.1)$ & $25(75.8)$ & $5(15.2)$ & NR & 33 & $26.909^{*}$ & .000 & $3(1)$ \\
\hline I felt connected with my teachers & NR & $23(69.7)$ & $7(21.2)$ & $3(9.1)$ & 33 & $20.364^{*}$ & .000 & $3(1)$ \\
\hline $\begin{array}{l}\text { I feel the online teaching strategies have enhanced my } \\
\text { clinical reasoning skills }\end{array}$ & $1(3.0)$ & $19(57.6)$ & $9(27.3)$ & $4(12.1)$ & 33 & $22.636^{*}$ & .000 & $3(1)$ \\
\hline $\begin{array}{l}\text { I feel the online teaching strategies prepared me } \\
\text { for critical thinking in clinical practice }\end{array}$ & $1(3.0)$ & $22(66.7)$ & $9(27.3)$ & $1(3.0)$ & 33 & $35.727^{*}$ & .000 & $3(1)$ \\
\hline $\begin{array}{l}\text { I practised clinical skills on persons, pets or } \\
\text { dummies at home }\end{array}$ & $1(3.0)$ & $1(3.0)$ & $17(51.5)$ & $14(42.4)$ & 33 & $26.030^{*}$ & .000 & $2(1)$ \\
\hline $\begin{array}{l}\text { I feel motivated to learn when engaging in online teaching } \\
\text { of clinical skills }\end{array}$ & $2(6.1)$ & $19(57.6)$ & $7(21.2)$ & $5(15.2)$ & 33 & $20.212^{*}$ & .000 & $3(1)$ \\
\hline I enjoyed the online teaching strategies & $3(9.1)$ & $22(66.7)$ & $3(9.1)$ & $5(15.2)$ & 33 & $30.879^{*}$ & .000 & $3(1)$ \\
\hline I liked that I could engage in learning in my own space & $12(35.3)$ & $17(51.5)$ & $4(12.1)$ & NR & 33 & $7.818^{*}$ & .000 & $3(1)$ \\
\hline I enjoyed working a my own pace & $16(47.1)$ & $14(42.4)$ & $3(9.1)$ & NR & 33 & $8.909^{*}$ & .012 & $3(1)$ \\
\hline I found it easy to adapt to online teaching & $3(9.1)$ & $19(57.6)$ & $10(30.3)$ & $1(3.0)$ & 33 & $24.091^{\star}$ & .000 & $3(1)$ \\
\hline \multicolumn{9}{|l|}{ Challenges experienced } \\
\hline Unavailability of computer/smartphone & NR & $6(18.2)$ & $21(63.6)$ & $6(18.2)$ & 33 & $13.636^{*}$ & .001 & $2(0)$ \\
\hline Problems with internet/connectivity & $8(24.2)$ & $21(63.6)$ & $2(6.1)$ & $2(6.1)$ & 33 & $29.182^{*}$ & .000 & $3(1)$ \\
\hline Distractions during remote classes & $3(9.1)$ & $13(39.4)$ & $16(48.5)$ & $1(3.0)$ & 33 & $19.727^{*}$ & .000 & $2(1)$ \\
\hline Not enough time to complete learning objectives & $1(3.0)$ & $4(12.1)$ & $25(75.8)$ & $3(9.1)$ & 33 & $45.909^{*}$ & .000 & $2(0)$ \\
\hline Poor quality of media used by lecturers & NR & $4(12.1)$ & $27(81.8)$ & $2(6.1)$ & 33 & $35.091^{*}$ & .000 & $2(0)$ \\
\hline \multicolumn{9}{|l|}{ Overall Satisfaction } \\
\hline $\begin{array}{l}\text { I would recommend continued use of online } \\
\text { strategies in the teaching of clinical skills. }\end{array}$ & $7(21.2)$ & $14(42.4)$ & $11(33.3)$ & $1(3.0)$ & 33 & $11.485^{\mathrm{b}}$ & .009 & $3(1)$ \\
\hline
\end{tabular}

*Values are statistically significant $(p<.01)$. 
Table 3. Student perception of the effectiveness of online teaching strategies for Clinical skills.

\begin{tabular}{|c|c|c|c|c|c|c|c|c|}
\hline Item & $\begin{array}{l}\text { Very Effective } \\
(\%)\end{array}$ & Effective (\%) & $\begin{array}{l}\text { Somewhat } \\
\text { Effective (\%) }\end{array}$ & $\begin{array}{l}\text { Not Effective } \\
\text { at all (\%) }\end{array}$ & Total & $\begin{array}{l}\text { Chi Squared } \\
\left(\chi^{2}\right)\end{array}$ & $P$ value & $\begin{array}{l}\text { Median } \\
\text { (IQR) }\end{array}$ \\
\hline \multicolumn{9}{|c|}{ Online Learning Environment } \\
\hline Remember clinical skills & $1(3.0)$ & $10(30.3)$ & $20(60.6)$ & $2(6.1)$ & 33 & $28.212^{*}$ & .000 & $1(1)$ \\
\hline Understand clinical skills & $1(3.0)$ & $9(27.3)$ & $20(60.6)$ & $3(9.1)$ & 33 & $26.515^{*}$ & .000 & $1(1)$ \\
\hline Acquire clinical skills & $\mathrm{NR}$ & $4(12.1)$ & $12(36.4)$ & $17(51.5)$ & 33 & $7.818^{* *}$ & .020 & $0(1)$ \\
\hline Supplement clinical skills & $1(3.0)$ & $10(30.3)$ & $19(57.6)$ & $3(9.1)$ & 33 & $24.091^{*}$ & .000 & $1(1)$ \\
\hline Self-study of clinical skills & $7(21.2)$ & $7(21.2)$ & $18(54.5)$ & $1(3.0)$ & 33 & $18.273^{*}$ & .000 & $1(1)$ \\
\hline $\begin{array}{l}\text { Prepare for OSCE/clinical } \\
\text { clerkship examinations }\end{array}$ & NR & $8(24.2)$ & $14(42.4)$ & $11(33.3)$ & 33 & 1.636 & .441 & $1(2)$ \\
\hline
\end{tabular}

${ }^{*}$ Values are statistically significant $(p<.05) .{ }^{*}$ Values are statistically significant $(p<.01)$.

\subsection{Teachers}

A total of 11 clinical teachers responded out of 15 which represents a response rate of $73.3 \%$. The age range was $31-52$ years old with a mean of $43.91 \pm 6.964$ and $81.8 \%$ were male. The teachers were from a range of disciplines (Restorative Dentistry, Oral Diseases and Paediatric Dentistry) and had varying levels of years of teaching experience from $2-26$ years with a mean of $15.18 \pm 7.846$. The majority (81.8\%) had formal training in online delivery before COVID-19. The Cronbach's alpha of the teachers' questionnaire was found to be .801 which is very good level of reliability.

\subsection{Teachers' Perception of the Effectiveness of Online Teaching Strategies}

The teaching strategies employed by the teachers are given in Table 4 and in addition breakout room discussions, polls and asynchronous assessments. Only the PowerPoint $\chi^{2}$ was found to be significant in Table $4(p<.01)$. The teachers' perceptions of the effectiveness of online teaching strategies are given in Table 5. Given the smaller numbers of teachers and responses the categories of strongly agree and agree were grouped and disagree and strongly disagree were also grouped for analysis. Overall the majority of teachers $(72.7 \%-92.9 \%$, with Median $=4, \mathrm{IQR}=3$ or 1 or 0 ) perceived that they created an enthusiastic online environment, effectively communicated with the students, engaged students in clinical reasoning and critical thinking and gave formative feedback. However, teachers were equally divided $(50 \%$, with Median $=2.5, \mathrm{IQR}=3$ ) on whether or not they perceived that they prepared students to practice clinical skills. Also, $45.5 \%$ (with Median $=4, \mathrm{IQR}=3$ ) did not feel connected with their students. Although the majority of teachers $(72.7 \%-81.4 \%$, with Median $=4$, IQR $=3$ or 1) felt they had a conducive home environment, were adequately equipped and confident to deliver online teaching, nearly two-thirds did not perceive it be easy to adapt to online teaching $(63.6 \%$, with Median $=4$, IQR $=3)$. Only the following items were statistically significant (either $P<.01$ or $P<.05$ ): engaged my 
students in clinical reasoning, effectively gave formative feedback, confident in my ability to deliver online teaching, felt adequately equipped for online training.

Table 4. Teaching strategies.

\begin{tabular}{|c|c|c|c|c|c|}
\hline $\begin{array}{l}\text { What online teaching strategies did you employ } \\
\text { during the period of emergency remote teaching? }\end{array}$ & No (\%) & Yes (\%) & Total & Chi-Squared $\left(\chi^{2}\right)$ & $P$-value \\
\hline Clinical videos (recorded at the UWI) & $7(70)$ & $3(30)$ & 10 & 1.600 & .206 \\
\hline Clinical videos (recorded by others e.g. YouTube videos) & $4(40)$ & $6(60)$ & 10 & .400 & .527 \\
\hline Online simulations & $6(60)$ & $4(40)$ & 10 & .400 & .527 \\
\hline PowerPoint presentation & $1(9.1)$ & $10(90.9)$ & 11 & $7.364^{*}$ & .007 \\
\hline Demonstration of skills by lecturer & $7(70)$ & $3(30)$ & 10 & 1.600 & .206 \\
\hline Virtual ward rounds/clinic visits & $10(100)$ & $0(0)$ & 10 & \multicolumn{2}{|c|}{$\begin{array}{l}\text { This variable is constant. } \chi^{2} \\
\text { cannot be performed. }\end{array}$} \\
\hline Discussion of clinical cases & $0(0)$ & $11(100)$ & 11 & \multicolumn{2}{|c|}{$\begin{array}{l}\text { This variable is constant. } \chi^{2} \\
\text { cannot be performed }\end{array}$} \\
\hline
\end{tabular}

${ }^{\star}$ Values are statistically significant $(p<.01)$.

Table 5. Clinical teacher perception of the effectiveness of online teaching strategies.

\begin{tabular}{|c|c|c|c|c|c|c|}
\hline Item & $\begin{array}{l}\text { Strongly } \\
\text { Agree - Agree (\%) }\end{array}$ & $\begin{array}{l}\text { Strongly Disagree } \\
\text { - Disagree (\%) }\end{array}$ & Total & $\begin{array}{l}\text { Chi-Squared } \\
\left(\chi^{2}\right)\end{array}$ & $P$-value & $\begin{array}{l}\text { Median } \\
\text { (IQR) }\end{array}$ \\
\hline \multicolumn{7}{|l|}{ Online Learning Environment } \\
\hline Created an enthusiastic/ stimulating learning environment & $8(72.70)$ & $3(27.3)$ & 11 & 2.273 & .132 & $4(3)$ \\
\hline Engaged my students in clinical reasoning & $10(90.9)$ & $1(9.1)$ & 11 & $7.364^{*}$ & .007 & $4(3)$ \\
\hline Effectively gave formative feedback & $10(90.9)$ & $1(9.1)$ & 11 & $7.364^{*}$ & .007 & $4(0)$ \\
\hline Felt connected with my students & $6(54.5)$ & $5(45.5)$ & 11 & .091 & .763 & $4(3)$ \\
\hline $\begin{array}{l}\text { Effectively communicated with my students during online } \\
\text { delivery }\end{array}$ & $8(72.70)$ & $3(27.3)$ & 11 & 2.273 & .132 & $4(1)$ \\
\hline Prepared students to practice clinical skills & $5(50.0)$ & $5(50.0)$ & 10 & .000 & 1.000 & $2.5(3)$ \\
\hline Conducive home environment to deliver online teaching & $8(72.70)$ & $3(27.3)$ & 11 & 2.273 & .132 & $4(1)$ \\
\hline Easy to adapt to online teaching & $4(36.4)$ & $7(63.6)$ & 11 & .818 & .366 & $4(3)$ \\
\hline Confident in my ability to deliver online teaching & $9(81.8)$ & $2(18.2)$ & 11 & $4.455^{\star *}$ & .035 & $4(3)$ \\
\hline Teaching online was enjoyable & $7(70)$ & $3(30)$ & 10 & 1.600 & .206 & $4(3)$ \\
\hline Felt adequately equipped for online training & $9(81.8)$ & $2(18.2)$ & 11 & $4.455^{\star *}$ & .035 & $4(1)$ \\
\hline \multicolumn{7}{|l|}{ Technical Support } \\
\hline No or minimal connectivity issues & $6(60)$ & $4(40)$ & 10 & .400 & .527 & $4(3)$ \\
\hline Safe and secure online teaching platform & 10 & NR & 10 & \multicolumn{3}{|c|}{$\begin{array}{l}\text { This variable is constant. } \chi^{2} \text { cannot be } \\
\text { performed. }\end{array}$} \\
\hline Full technical support from the ICT staff & 10 & NR & 10 & \multicolumn{3}{|c|}{$\begin{array}{l}\text { This variable is constant. } \chi^{2} \text { cannot be } \\
\text { performed. }\end{array}$} \\
\hline Satisfied with online teaching of clinical skills & $6(60)$ & $4(40)$ & 10 & .400 & .527 & $4(3)$ \\
\hline
\end{tabular}

${ }^{* *}$ Values are statistically significant $(p<.05) .{ }^{*}$ Values are statistically significant $(p<.01)$. 


\section{Discussion}

Prior to COVID-19, positive perceptions were reported by medical students to the use of online videos for clinical skills training (Jang \& Kim, 2014). Online strategies for clinical skills training have been shown to be effective adjuncts to face-to-face instruction in most medical education programmes (Kelly et al., 2009). Dental students' perceptions with regard to online learning were also positive (Asiry, 2017). The success of online learning depends on a number of factors such as ease of access for students and teachers, connectivity (Parsazadeh et al., 2013) and also the teacher expertise in online teaching and online content (Oliver, 2001). Despite the acceptance of online learning, it was not a major part of the dental curriculum in Trinidad. Our courses were not designed for online platform teaching and like many other dental schools in the same position, it is necessary to understand from the student perspective their views on this. Students' evaluation of their attitudes to online learning is important for determining the success of any online learning system (Pahinis et al., 2007) and especially during this COVID-19 global pandemic.

In this study, students had positive perceptions of online teaching strategies delivered by the teachers in the dental school and felt connected to them. This is in agreement with other studies where positive perceptions were also reported amongst dental students before the COVID-19 pandemic (Asiry, 2017; Smith et al., 2012; Turkylimaz et al., 2019). However, this is in contrast to a recent study from Pakistan conducted on medical and dental students that showed overall $77 \%$ of students having negative perceptions towards e-learning during the lockdown and the majority preferred face to face teaching over e-teaching (Abbasi et al., 2020).

Most students in this study also found that online teaching strategies enhanced their clinical reasoning and critical thinking skills and would recommend continued use of online teaching. This was similar to findings from New York University College of Dentistry who concluded that e-learning may be used successfully in a dental school's curriculum to enhance students' learning especially in the clinical curriculum (Turkylimaz et al., 2019). However, when it came to actually acquiring clinical skills $87.9 \%$ of our students found it to be not effective at all or only somewhat effective. This is in agreement with another study at Harvard School of Dental Medicine where most students felt that their didactic learning had not changed however a majority of students felt that their preclinical learning had worsened and similarly the clinical students also felt that their learning had worsened (Van Doren et al., 2020). Dental students in Trinidad and at Harvard both have negative perceptions of the effectiveness of online teaching strategies when it comes to the acquisition of clinical skills in particular. Dentistry is unique in that it requires hands-on clinical training (Van Doren et al., 2020) and the suspension of direct patient care, which is a key component of the dental curriculum, is the biggest challenge in the COVID-19 pandemic (Iyer et al., 2020). 
The students' other main challenge was with connectivity/internet issues $(87.9 \%)$ and this is similar to other studies where $82.1 \%$ of students felt unavailability of the internet was a learning barrier with high impact on them (Kujan et al., 2015) and others that reported technical difficulties with low connection speeds and access (Jang \& Kim, 2014; Parsazadeh et al., 2013). Variability in student access to quality internet can compromise student achievements in remote learning, especially in developing countries (Machado et al., 2020). Students also experienced distractions at home such as poor wifi, having no dedicated space for learning at home with other persons in the vicinity and distracted by social media while on online class.

The teachers also reported positive perceptions of the effectiveness of online teaching strategies in effectively communicating with students and engaging the students in critical thinking and clinical reasoning. Although the teachers felt confident and adequately equipped for online teaching, they still felt it was not easy to adapt to online teaching, despite over $80 \%$ of teachers having formal training in online teaching prior to COVID-19. However, only half perceived that they adequately prepared their students for clinical practice.

Students' perceptions are similar to teachers' perceptions in both being positive to the online teaching strategies but both groups reflected concerns over the acquisition of clinical skills. Manual dexterity and fine motor skills are skills that must be achieved by dental students and it is difficult to replace experience with patients with e-learning strategies (Van Doren et al., 2020; Machado et al., 2020). An important area moving forward would be the online use of dental simulation but it is a challenge in terms of resources (Barabari \& Moharamzadeh, 2020) and expense (Machado et al., 2020) and also training pre-clinically on manikins is very difficult as the units are not portable to be used from home (Machado et al., 2020).

Students' perceptions differed to teachers' perceptions in that students felt more connected while teachers did not and also students felt it easy to adapt online while teachers did not perceive the transition to be easy. This could be due to the younger millennials (23 - 35 years old) being more comfortable online than the older teachers ( $31-52$ years old).

When considering the impact of COVID-19 on dental education, reports on the current and future perspectives (Meng et al., 2020; Machado et al., 2020; Barabari \& Moharamzadeh, 2020; Chavarría-Bolaños et al., 2020; Deery, 2020) all have raised varying aspects. As the COVID-19 global pandemic may continue for some time in the future and dental education may be interrupted from face to face activities, more e-learning strategies have to be utilised such as virtual patients with the simulation of real-life clinical scenarios as part of student training (Chavarría-Bolaños et al., 2020). Also, virtual reality technology may have to be developed for more mainstream use during the COVID-19 pandemic (Barabari \& Moharamzadeh, 2020).

There are very few research studies in the literature of the students' perceptions on dental education during the global pandemic at present and the limita- 
tions in comparing to those may be due to differences in programme structure, learning environment, teachers' expertise in online teaching or culture (Alshare et al., 2003).

\section{Conclusion}

Students' perceptions are similar to teachers' perceptions in that both are positive to the online teaching strategies but both groups reflected concerns over the acquisition of clinical skills. The challenge for dental education would be greater in developing countries like Trinidad to accomplish dental clinical training during a period of lockdown with limited resources. While online teaching strategies have been found in this study to be well accepted by the students, further research is necessary to examine if the required competencies are achieved.

\section{Acknowledgements}

The authors would like to thank the Year 5 dental students and clinical staff of the School of Dentistry, the University of the West Indies, Trinidad \& Tobago for participating in the study.

\section{Conflicts of Interest}

The authors declare no conflicts of interest regarding the publication of this paper.

\section{References}

Abbasi, S., Ayoob, T., Malik, A., \& Memon, S. I. (2020). Perceptions of Students Regarding E-Learning during Covid-19 at a Private Medical College. Pakistan Journal of Medical Sciences, 36, S57-S61. https://doi.org/10.12669/pjms.36.COVID19-S4.2766

Alshare, K., Al-Dwairi, M., \& Akour, I. (2003). Student Instructor Perception of Computer Technologies in Developing Countries: The Case of Jordan. Journal of Computer Information Systems, 43, 115-123.

Asiry, M. A. (2017). Dental Students' Perceptions of an Online Learning. The Saudi Dental Journal, 29, 167-170. https://doi.org/10.1016/j.sdentj.2017.03.005

Barabari, P., \& Moharamzadeh, K. (2020). Novel Coronavirus (COVID-19) and Dentistry-A Comprehensive Review of Literature. Dentistry Journal, 8, 53. https://doi.org/10.3390/dj8020053

Centers for Disease Control and Prevention (CDC) (2019). Guidance for Dental Settings. https://www.cdc.gov/coronavirus/2019-ncov/hcp/dental-settings.html

Chavarría-Bolaños, D., Gómez-Fernández, A., Dittel-Jiménez, C., \& Montero-Aguilar, M. (2020). E-Learning in Dental Schools in the Times of COVID-19: A Review and Analysis of an Educational Resource in Times of the COVID-19 Pandemic. International Journal of Dental Sciences, 22-23, 69-86. https://doi.org/10.15517/ijds.2020.41813

Deery, C. (2020). The COVID-19 Pandemic: Implications for Dental Education. Evidence-Based Dentistry, 21, 46-47. https://doi.org/10.1038/s41432-020-0089-3

Iyer, P., Aziz, K., \& Ojcius, D. M. (2020) Impact of COVID-19 on Dental Education in the United States. Journal of Dental Education, 84, 718-722.

https://doi.org/10.1002/jdd.12163 
Jang, H. W., \& Kim, K.-J. (2014). Use of Online Clinical Videos for Clinical Skills Training for Medical Students: Benefits and Challenges. BMC Medical Education, 14, Article No. 56. https://doi.org/10.1186/1472-6920-14-56

Kelly, M., Lyng, C., McGrath, M., \& Cannon, G. (2009). A Multi-Method Study to Determine the Effectiveness of, and Student Attitudes to, Online Instructional Videos for Teaching Clinical Nursing Skills. Nurse Education Today, 29, 292-300.

https://doi.org/10.1016/j.nedt.2008.09.004

Kujan, O., Hasan, R. A., Nasog, M., Badawi, T., Hanouneh, S., \& Nassani, M. (2015). Assessing Learning Barriers among Dental and Nursing Undergraduates: A Qualitative Study, Students' Perspectives. Oral Health and Dental Management, 14, 265-271.

Li, Q., Guan, X., Wu, P., Wang, X., Zhou, L., Tong, Y., Ren, R., Leung, K. S. M., Lau, E. H. Y., Wong, J. Y. et al. (2020). Early Transmission Dynamics in Wuhan, China, of Novel Coronavirus-Infected Pneumonia. New England Journal of Medicine, 382, 1199-1207. https://doi.org/10.1056/NEJMoa2001316

Machado, R. A., Bonan, R. R. F., Peres, D. E. C., \& Martelli, J. H. (2020). COVID-19 Pandemic and the Impact on Dental Education: Discussing Current and Future Perspectives. Brazilian Oral Research, 34. https://doi.org/10.1590/1807-3107bor-2020.vol34.0083

Meng, L., Hua, F., \& Bian, Z. (2020). Coronavirus Disease 2019 (COVID-19): Emerging and Future Challenges for Dental and Oral Medicine. Journal of Dental Research, 99, 481-487. https://doi.org/10.1177/0022034520914246

Oliver, R., (2001). Assuring the Quality of Online Leaning in Australian Higher Education. In A. E. A. D. N. M. Wallace (Ed.), Moving Online II Conference (pp. 222-231). Lismore: Southern Cross University.

Pahinis, K., Stokes, C. W., Walsh, T. F., \& Cannavina, G. (2007). Evaluating a Blended-Learning Course Taught to Different Groups of Learners in a Dental School. Journal of Dental Education, 71, 269-278. https://doi.org/10.1002/j.0022-0337.2007.71.2.tb04275.x

Parsazadeh, N., Zainuddin, N. M. M., Ali, R., \& Hematian, A. (2013). A Review on the Success Factors of e-Learning. In: The Second International Conference on e-Technologies and Networks for Development (pp. 42-49). Kuala Lumpur.

Peng, X., Xu, X., Li, Y., Cheng, L., Zhou, X., \& Ren, B. (2020). Transmission Routes of 2019-nCoV and Controls in Dental Practice. International Journal of Oral Science, 12, Article No. 9. https://doi.org/10.1038/s41368-020-0075-9

Peres, K. G., Reher, P., de Castro, R. D., \& Vieira, A. R. (2020). COVID-19 Related Challenges in Dental Education; Experiences from Australia, Brazil and the USA. Pesquisa Brasileira em Odontopediatria e Clínica Integrada, 20.

https://doi.org/10.1590/pboci.2020.130

Phelan, A. L., Katz, R., \& Gostin, L. O. (2020). The Novel Coronavirus Originating in Wuhan, China: Challenges for Global Health Governance. JAMA, 323, 709-710. https://doi.org/10.1001/jama.2020.1097

Quinn, B., Field, J., Gorter, R., Akota, I., Manzanares, M.-C., Paganelli, C., Davies, J., Dixon, J., Gabor, G., Mendes, R. A., Hahn, P., Vital, S., O’Brien, J., Murphy, D., \& Tubert-Jeannin, S. (2020). COVID-19: The Immediate Response of European Academic Dental Institutions and Future Implications for Dental Education. European Journal of Dental Education, 24, 811-814. https://doi.org/10.1111/eje.12542

Rafeek, R. N., Marchan, S. M., Naidu, R. S., \& Carrotte, P. V. (2004). Perceived Competency at Graduation among Dental Alumni of the University of the West Indies. Journal of Dental Education, 68, 81-88. 
https://doi.org/10.1002/j.0022-0337.2004.68.1.tb03741.x

Sahu, P. (2020). Closure of Universities Due to Coronavirus Disease 2019 (COVID-19): Impact on Education and Mental Health of Students and Academic Staff. Cureus, 12, e7541. https://doi.org/10.7759/cureus.7541

Smith, W., Rafeek, R., Marchan, S., \& Paryag, A. (2012). The Use of Video-Clips as a Teaching Aide. European Journal of Dental Education, 16, 91-96. https://doi.org/10.1111/j.1600-0579.2011.00724.x

Turkylimaz, I., Hariri, N. H., \& Jahangiri, L. (2019). Students' Perception of the Impact of E-Learning on Dental Education. J Contemp Dent Practice, 20, 616-621. https://doi.org/10.5005/jp-journals-10024-2568

US Department of Labor, Occupational Safety and Health Administration (2020). Guidance on Preparing Workplaces for COVID-19.OSHA 3990-03 2020.

Van Doren, E. J., Lee, J. E., Breitman, L. S., Chutinan, S., \& Ohyama, H. (2020). Students' Perceptions on Dental Education in the Wake of the COVID-19 Pandemic. Journal of Dental Education, Early View, 1-3. https://doi.org/10.1002/jdd.12300

World Health Organization (WHO) (2019). WHO's Coronavirus (COVID-19) Pandemic. https://www.who.int/emergencies/diseases/novel-coronavirus-2019/interactive-timelin e\#! 